\title{
PHENOLIC COMPOUNDS, SWEETNESS AND AMINO ACIDS CONTENT OF ONION CULTIVARS DISTRIBUTED IN EGYPTIAN LOCAL MARKETS AND THEIR RELATIONSHIP WITH ANTIOXIDANT ACTIVITIES
}

\author{
Yousif A. Elhassaneen \\ Department of Nutrition and Food Science, Faculty of Home Economics, \\ Minufiya University, Shebin El-Kom, Egypt. \\ Phone: 002-01005023515,Fax:002-048-227638, E-mail: yousif12@hotmail.com
}

\begin{abstract}
Phenolic compounds, sweetness and amino acids content of two onion (Allium cepa L.) cultivars, white (Giza-6) and red (Giza-20) onions and their relationship with antioxidant activities were assessed. Data analysis showed that the white onion variety has higher values for protein, ash, fiber, total carbohydrates and total energy while red once has the lowest dry matter content (12.61\%). Regarding mineral and vitamins levels, the white onion variety represents higher levels of $\mathrm{K}, \mathrm{Ca}, \mathrm{Mg}, \mathrm{P}, \mathrm{Zn}, \mathrm{Cu}$ and $\mathrm{Mn}$ while $\mathrm{Fe}, \mathrm{S}$, Se and vitamin $C$ were higher in red variety. A white variety shows higher value of total amino acids (1460 $\mathrm{mg} / 100 \mathrm{~g} \mathrm{FW})$ than red once [1345 $\mathrm{mg} / 100 \mathrm{~g}$ $F W)$ and the opposite was observed for sulphur-containing amino acid (cysteic, S-carboxymethyl cystein ( $S$-CM cystein), cystine and methionine].

The total single sugars detected in red onion $(4.78 \mathrm{~g} / 100 \mathrm{~g} \mathrm{FW})$ are superior to in white $(3.91 \mathrm{~g} / 100 \mathrm{~g} \mathrm{FW})$. Glucose and fructose levels are higher in the red onion than the white once and the opposite with sucrose. Concerning pungency, white variety can be classified as very sweet (6.24 $\mu \mathrm{mol}$ pyruvic acid/g $F W$ ) and red as sweet (8.37 $\mu$ mol pyruvic acid/g $F W)$. A negative correlation in sucrose and glucose and a positive correlation in fructose, sulphur, vitamin $C$, sulphur-containing amino acids and phenolics content with pungency were also observed. The phenolic acids, flavonols, anthocyanins and total phenolics content in red variety $(81.59,70.38,7.56$ and $187.17 \mathrm{mg} / 100 \mathrm{~g} \mathrm{FW}$, respectively) were higher than for white once (72.47, $32.49,4.90$ and $131.65 \mathrm{mg} / 100 \mathrm{~g} F$, respectively). Consequently, antioxidant activity was higher for the red variety. Statistical analysis indicates that total phenolic compounds beside other factors including Se and sulphur-containing amino acid contents play the major role in the antioxidant activity of onion bulbs.
\end{abstract}

Conclusively, the present data indicates that white onion variety shows higher nutritional value while the potential health benefits related to the presence of antioxidant compounds and other factors were higher in onion red variety.

Key word: Allium cepa L.; sulphur-containing amino acids; sweetness; phenolics; Antioxidants 


\section{INTRODUCTION}

Onions (Allium cepa L.), have world-wide importance, ranking second among all vegetables in economic importance after tomatoes (Griffiths et al., 2002). The average intake in the world is $7 \mathrm{~kg}$ per capita ${ }^{-1}$. year ${ }^{-1}$, being Libya $\left(32 \mathrm{~kg}\right.$ per capita ${ }^{-1}$. year $^{-1}$ ) and Turkey (27 kg per capita ${ }^{-1} \cdot$ year $^{-1}$ ) the main consumers (FAOSTAT, 2002). In Egypt, onion is the third vegetable more consumed ( $15 \mathrm{~kg}_{\text {per }}$ capita $^{-1}$.year $\left.{ }^{-1}\right)$, after potato and tomatoes, and it is cultivated all over the country concentration in delta area and Upper Egypt (84.3 \% of total area) and new land areas (15.7 \%), being white (Giza-6) and red (Giza-20) onions the most produced varieties. The current production area is being around 122,552 Feddan with total production 1.3 million ton. According to the physical and chemical properties, the red onion variety is predominant in the Egyptian diet while the white onion directed to dehydration process. Dehydrated onion production has increased by at least $40 \%$ over the past ten years with current production being around 10,000 metric Ton per year ${ }^{-1}$.

Beside the nutritional value and unique flavour, onion shows a variety of pharmacological and nutritional effects such as growth-inhibition of tumor and microbial cells, immunostimulatory properties, enhancing reproduction, improving the growth performance (body weight gain, feed consumption, and feed conversion), reduction of cancer risk and protection against cardiovascular diseases, diabetes as well as ageing, which are attributed to phenolic compounds (flavonoids, antocyanins, phenolic acids and flavonols), organosulphur compounds, vitamins and some minerals (Teyssier et al., 2001; Furusawa et al., 2003; Kamal and Daoud 2003; Campos et al., 2003; Gabler et al., 2003; Ismail et al., 2003; and Wang et al., 2005). Also, the ability of these compounds to acts as antioxidants has been demonstrated in the literature. Several researchers have investigated the antioxidant activity of flavonoid compounds and have attempted to define the structural characteristics of flavonoids that contribute to their activity (Nieto et al., 1993 and Foti et al., 1996). Phenolic acids, such as caffeic, chlorogenic, ferulic, sinapic, p-coumaric acids, vanillic, syringic and p-hydroxybenzoic appear to be active antioxidants (Larson, 1988 and El-Sadany, 2001). Vitamin C has a protective function against oxidative damage and a powerfull quencher of singlet oxygen $\left(1 \mathrm{O}_{2}\right)$, hydroxyl $(\mathrm{OH})$ and peroxyl $\left(\mathrm{RO}_{2}\right)$ radicals, (Niki, 1991). Antioxidant activity is fundamental property important for life. Many of the biological functions, such as antimutagenicity, anticarcinogenicity, and antiaging, among others, originate from this property (Huang et al., 1992 and Cook and Samman, 1996).

The antioxidant activity of several plant materials including onion bulbs has recently been reported (Velioglu et al., 1998 and Rodrigues et al., 2003); however, information on the relationship between antioxidant activity and phenolics content and composition of onion bulbs is not available.

Therefore, the objective of this study was to determine the phenolic compounds, sweetness amino acids contents and minerals in different onion varieties distributed in Egyptian local markets and to explore relationship(s) between these components and antioxidant activity. 


\section{MATERIALS AND METHODS}

\section{MATERIALS}

Onion samples were obtained from the most widespread local cultivar in the typical area of production, red onion (Giza-20) from Tala city, Minufiya Governorate and white onion (Giza-6) from Bani Mazar city, Minia Governorate, Egypt. After harvesting (mid of March), the onions were stored with skins, for three months at an average temperature of $25 \pm 2{ }^{0} \mathrm{C}$. When bulbs were ready for sale (Mid of June), Twenty bulbs for each sample were selected to obtain the representative samples. Analyses were carried out on the edible portion (only the internal part of bulbs) and the results are represented as the mean value of five samples (fresh weight, FW) \pm SD.

\section{CHEMICALS}

Phenolic compounds, sugars and sodium pyruvate standards were purchased from Fluka Chemical Co., Switzerland, while vitamin $C$ and amino acids standards from Sigma Chemical Co., St. Louis, Mo.

\section{EQUIPMENT'S}

In the present study, a SP Thermo Separation Products Liquid Chromatograph (Thermo Separation products, San Jose, CA, USA) was used with a pump Consta Metvic 4100, a Spectra Series AS100, Spectra System UV 1000 UV/Visible Spectrophotometer Detector, Spectra System FL 3000 and a PC 1000 system software. The columns used (Alltech, Baltimore, USA) were The column used was a reversed-phase water Spherosorb ODC-2 $(3 \mu \mathrm{M} ; 150 \times 4.6 \mathrm{~mm}$ I.d., Alltech USA) for phenolics; a guard column $7.5 \times 3.2 \mathrm{~mm}$ containing $5 \mu \mathrm{m}, \mathrm{C}-18$ reversed phase Econosphere was attached directly to a reversed-phase C-18 column $(3 \mu \mathrm{m} ; 150 \mathrm{x} 4.6$ mm I.d. (Alltech, Carnforth Lancashire, UK) for amino acids; a normal Econosphere $\mathrm{NH} 2(5 \mu \mathrm{M}, 250 \times 4.6 \mathrm{~mm}$ I.d., Alltech USA) for sugars; and a reversed-phase water Adsorbosil $\mathrm{C}_{18}(5 \mu \mathrm{M}, 100 \mathrm{~mm} \times 4.6 \mathrm{~mm}$ I.d., Alltech USA) for vitamin $\mathrm{C}$ analysis.

\section{ANALYTICAL METHODS}

Gross chemical composition: Moisture, protein (T.N. $\times 6.25$, micro - kjeldahl method using semiautomatic apparatus, Velp Scientifica company, Italy), fat (Soxhelt semiautomatic apparatus, Velp Scientifica Company, model SER 148/3 ,Italy, petroleum ether solvent), fiber (automatic extractor, Velp Scientifica Company, model FIWE 6,Italy) and ash contents were determined using the methods described in the A.O.A.C. (1995). Total carbohydrates calculated by differences:

Carbohydrates $(\%)=100-(\%$ moisture $+\%$ protein $+\%$ fat $+\%$ Ash $+\%$ fiber $)$

Minerals: Bulbs defatted samples are digested as described by Singh et al., (1991), the different minerals ( $\mathrm{K}, \mathrm{Ca}, \mathrm{Mg}, \mathrm{Fe}, \mathrm{Zn}, \mathrm{Cu}, \mathrm{Mn}$ and $\mathrm{Se}$ ) were analyzed in atomic absorption spectrophotometer, using a Perkin - Elmer, Model 2380. Sulphur was determined with a turbidimetry method and P determined by colorimetric method as described by APHA, (1999). 
Vitamins: Vitamin C was extracted according to the methods of Moeslinger et al., (1994). The chromatographic conditions were flow rate, $1 \mathrm{ml} / \mathrm{min}$; detection, UV absorption at $254 \mathrm{~nm}$, volume of injection, $20 \mu \mathrm{l}$; temperature, room temperature, and mobile phase composition was an isocratic system of $100 \%$ methanol.

Sugars: To determine fructose, glucose and sucrose, $1 \mathrm{~g}$ of fresh onions was added to $\mathrm{CH}_{3} \mathrm{CN} / \mathrm{H}_{2} \mathrm{O}$ (4:1) up to $10 \mathrm{~mL}$ and homogenized in an Ultra Moulinex blender. After, the samples were centrifuged, filtered and analysed in HPLC according to Gennaro et al. (2002). The chromatographic conditions were flow rate, 4 $\mathrm{ml} / \mathrm{min}$; detection, RI, volume of injection, $20 \mu \mathrm{l}$; temperature, room temperature, and mobile phase composition was an isocratic system of acetonitril : water (75:25).

Amino acids: Amino acids were analyzed in HPLC according to the method of Lindroth and Mopper (1979). Chromatographic separations were carried out with a 150 x 4.6 mm stainless-steel Econosphere C-18 reversed-phase column containing 3 $\mu \mathrm{m}$ packing (Alltech, Carnforth Lancashire, UK). A guard column $7.5 \times 3.2 \mathrm{~mm}$ containing $5 \mu \mathrm{m}, \mathrm{C}-18$ reversed phase packing (Alltech, Carnforth Lancashire, UK) was attached directly to analytical column. A gradient elution using methanol was performed for better analytes separation and column cleansing prior to subsequent injections. The elution profile was : 0-2 $\mathrm{min}, 5-10 \% \mathrm{~B} ; 2-11 \mathrm{~min}, 10-35 \% \mathrm{~B} ; 11-20$ $\min , 35-65 \% \mathrm{~B} ; 20-22 \%, 65-100 \% \mathrm{~B} ; 22-24 \mathrm{~min}$, isocratic $100 \% \mathrm{~B} ; 24-30 \mathrm{~min}, 100-$ $5 \%$ B. Separations were performed at ambient temperature using a flow rate $1.5 \mathrm{~mL}$ $\mathrm{min}^{-1}$. The fluorescence detector was set to operating at $340 \mathrm{~nm}$ in the excitation and $455 \mathrm{~nm}$ in the emission mode.

Phenolic acid: Fresh onion bulbs were cut into small cubes, which were placed into freeze-drying jars, and then frozen in liquid nitrogen. The frozen samples were lyophilized (Birchover Ltd, Letchworth, Herts) for $72 \mathrm{~h}$ then grounded in a wily mill (Tecator, Boulder, Co, USA) fitted with 60-mesh screen sieve. The obtained samples powder were packed in opaque air tied bags and stored at $-20{ }^{\circ} \mathrm{C}$ until HPLC analysis. The phenolic acid extracts were prepared according to the method of Onyencho and Hettiarachchy (1993). The chromatographic conditions were as following: Flow rate, $1 \mathrm{ml} / \mathrm{min}$; detection, UV absorption at $265 \mathrm{~nm}$, fluorescence Ex: $250 \mathrm{~nm}-\operatorname{Em} \lambda$ : $400 \mathrm{~nm}$; volume of injection, $20 \mu \mathrm{l}$; and temperature, room temperature. The mobile phase composition was an isocratic system of methanol and ammonium acetate buffer, $\mathrm{pH} 5.4(12: 88, \mathrm{v} / \mathrm{v})$.

Flavonols: Flavonols were extracted and analyzed in HPLC according to the method of Hertog et al. (1992). Sample peaks were quantified with the external standard method .

Anthocyanins: The anthocyanins were extracted from onion tissues by suspending $1.5 \mathrm{~g}$ of homogenized tissue in $5 \mathrm{~mL}$ of methanol $(0.1 \% \mathrm{HCl})$ at room temperature for $10 \mathrm{~min}$. The extract was filtered and used for HPLC analyses as described by Fossen et al. (1996) with some modification described by Gennaro et al. (2002). 
Pungency: Pyruvic acid concentration was determined using the Schwimmer and Weston (1961) method. A representative sample (15 quarters, one from each bulb) of each cultivar was crushed in an electric mincer, incubated with 2,4dinitrophenylhydrazine and read the absorbance at $420 \mathrm{~nm}$ on a spectrophotometer for total pyruvic acid concentration, that were determined against a sodium pyruvate standard curve.

Antioxidant Activity: Minced bulbs (5 g) were extracted with $80 \%$ aqueous methanol $(100 \mathrm{ml})$ on an orbital shaker for $120 \mathrm{~min}$ at $25{ }^{0} \mathrm{C}$. The mixture was subsequently filtered (Whatman No. 5) on a Buchner funnel, and the filtrate was assayed for antioxidant activity. Antioxidant activity of onion extracts and standards ( $\alpha$-tocopherol, BHA, and BHT; Sigma Chemical Co., St. Louis, Mo) was determined according to the $\beta$-carotene bleaching method following a modification of the procedure described by Marco (1968). Antioxidant activity was calculated in four different ways. In the first, absorbance was plotted against time, as a knit curve, and the absolute value of slope was expressed as antioxidant value (AOX). Antioxidant activity (AA) was all calculated as percent inhibition relative to control using the following equation (Al-Saikhan et al., 1995).

$\mathrm{AA}=\left[\left(\mathrm{R}_{\text {control }}-\mathrm{R}_{\text {sample }}\right) / \mathrm{R}_{\text {control }}\right] \times 100$

Where $\mathrm{R}$ control and $\mathrm{R}$ sample were the bleaching rates of $\beta$-carotene in reactant mixture without antioxidant and with plant extract, respectively.

The third method of expression based on the oxidation rate ratio (ORR) was calculated according to the method of Marinova et al., (1994) using the equation:

$\mathrm{ORR}=\mathrm{R}_{\text {sample }} / \mathrm{R}_{\text {control }}$

Where $\mathrm{R}_{\text {control }}$ and $\mathrm{R}_{\text {sample }}$ are the same in the previous equation.

In the fourth method, the antioxidant activity coefficient (AAC) was calculated as described by Mallet et al., (1994).

$\left.(\mathrm{AAC})=\left[\left(\mathrm{Abs}_{\mathrm{S}} 120-\mathrm{Abs}_{\mathrm{C}} 120\right) / \mathrm{Abs}_{\mathrm{C} 0}-\mathrm{Abs}_{\mathrm{C}} 120\right)\right] \times 1000$

where: Abs s 120 was the absorbance of the antioxidant mixture at time $120 \mathrm{~min}$, Abs $\mathrm{C}_{120}$ was the absorbance of the control at time $120 \mathrm{~min}$ and Abs $\mathrm{C}_{0}$ was the absorbance of the control at zero time.

Total phenolics. Two grams of the minced bulb was extracted for $2 \mathrm{~h}$ with 20 $\mathrm{mL}$ of $80 \% \mathrm{MeOH}$ containing $1 \%$ hydrochloric acid at room temperature on an orbital shaker set at $200 \mathrm{rpm}$. The mixture was centrifuged at $1000 \mathrm{~g}$ for $15 \mathrm{~min}$ and the supernatant decanted into $4 \mathrm{~mL}$ vials. The pellets were combined and used for total phenolics assay. Total phenolics were determined using Folin-Ciocalteu reagent (Singleton and Rossi, 1965). Results are expressed as ferulic and equivalents.

\section{Statistical analysis:}

An analysis of variance was performed to compare differences between varieties using Student $t$ - test.

The correlation studies were performed by using MINITAB 12 computer program (Minitab Inc., State College, PA). 


\section{RESULTS AND DISCUSSION}

Chemical composition, mineral, vitamin $\mathbf{C}$ and amino acids levels. The white onion has higher levels of protein, ash, fiber, total carbohydrates and total energy respect to the white once (Table 1). However, red onion has higher water content that can interfere negatively with storage capacity and using in dehydration process. In the present study, one $\mathrm{kg}$ of dehydrated onion is produced from $6.19 \mathrm{~kg}$ of fresh white onion compared to $7.42 \mathrm{~kg}$ of red once.

Table 1. Gross chemical composition ( $\mathrm{g} / 100 \mathrm{~g}$ of edible portion) and total energy ( Kcal / 100 gm) of onion varieties.

\begin{tabular}{lccc}
\multirow{2}{*}{ Chemical composition } & \multicolumn{2}{c}{ Onion variety } & \\
\cline { 2 - 3 } & White & Red & \multirow{2}{*}{ Significance } \\
\cline { 2 - 3 } Moisture & $84.92 \pm 3.31$ & $87.39 \pm 2.29$ & $* * *$ \\
Total protein $($ T.N $\times \mathbf{6 . 2 5 )}$ & $1.77 \pm 0.24$ & $1.53 \pm 0.17$ & $*$ \\
Crude fat (Pet. ether extract) & $0.12 \pm 0.03$ & $0.15 \pm 0.04$ & NS \\
Ash & $0.78 \pm 0.09$ & $0.62 \pm 0.11$ & $* * *$ \\
Fiber & $1.17 \pm 0.32$ & $0.98 \pm 0.15$ & $* *$ \\
Carbohydrate & $11.24 \pm 1.15$ & $9.33 \pm 1.21$ & $* *$ \\
Total Energy $($ Kcal / 100 gm) & $53.12 \pm 3.21$ & $44.79 \pm 4.78$ & $*$ \\
& & \\
\hline NS, Non significant, & $*, * *, * * *$ Significant at $\mathrm{P}<0.05, \mathrm{P}<0.01$ and $\mathrm{P}<0.0001$, respectively.
\end{tabular}

Regarding mineral and vitamins levels, the white onion has higher levels of $\mathrm{K}$, $\mathrm{Ca}, \mathrm{Mg}, \mathrm{P}, \mathrm{Zn}, \mathrm{Cu}$ and $\mathrm{Mn}$ respect to the red once (Table 2). However, red onion has higher Fe, S, Se and ascorbic acid.

The present data are not in accordance with that obtained by Rodrigues et al., (2003) who found that Povoa red onion in Northwest Portugal has higher level in all minerals determined than the white once. This variation explained that the effect of regional varieties, environment beside the genetic factors. A higher level of Se in both white and red onion bulbs varieties could be played a significant role in nutritional point of view as a functional plant food. The amounts of white and red onion bulbs consumed by adultman to cover the daily requirements in Se $(70 \mu \mathrm{g})$ were 6.67 and $4.17 \mathrm{~g}$ respectively. Selenium $(\mathrm{Se})$ is an essential trace element. Its importance for human and animal metabolism has become apparent more recently, spurred by the discovery of a Se-dependent enzyme, glutathione peroxidase (widely distributed in tissues), and suggestive evidence that selenium plays a role in the prevention of certain forms of cancer (reviewed by Linder, 1991 and Packer, 1992). 
Table 2. Mineral and vitamin levels of onion varieties (mg/100g of edible portion).

\begin{tabular}{|c|c|c|c|}
\hline \multirow{2}{*}{ Minerals and vitamins } & \multicolumn{2}{|c|}{ Onion vVariety } & \multirow{2}{*}{ Significance } \\
\hline & White & Red & \\
\hline \multicolumn{4}{|l|}{ Minerals: } \\
\hline $\mathrm{K}$ & $214 \pm 21$ & $183 \pm 17$ & $* *$ \\
\hline $\mathrm{Ca}$ & $31 \pm 6.2$ & $22.5 \pm 4.8$ & $*$ \\
\hline $\mathrm{Mg}$ & $21 \pm 3.4$ & $14.43 \pm 2.1$ & $*$ \\
\hline $\mathrm{P}$ & $39 \pm 5.6$ & $28.54 \pm 4.2$ & $* *$ \\
\hline $\mathrm{Fe}$ & $1.61 \pm 0.43$ & $2.01 \pm 0.58$ & $* * *$ \\
\hline $\mathrm{Zn}$ & $0.81 \pm 0.26$ & $0.56 \pm 0.09$ & $* *$ \\
\hline $\mathrm{Cu}$ & $0.14 \pm 0.05$ & $0.09 \pm 0.03$ & $*$ \\
\hline Mn & $0.41 \pm 0.08$ & $0.40 \pm 0.09$ & NS \\
\hline S & $48.23 \pm 6.9$ & $75.22 \pm 8.34$ & $* * *$ \\
\hline $\mathrm{Se}$ & $1.05 \pm 0.11$ & $1.68 \pm 0.09$ & $* * *$ \\
\hline \multicolumn{4}{|l|}{ Vitamins: } \\
\hline Vitamin C (Ascorbic acid) & $13.84 \pm 2.9$ & $14.63 \pm 4.7$ & $*$ \\
\hline
\end{tabular}

The total amino acids levels in white onion $(1460 \mathrm{mg} / 100 \mathrm{~g} \mathrm{FW})$ is superior than in red (1345 mg/100g FW) (Table 3). The studying of amino acid profiles indicated that the white onion has higher levels of almost amino acids except sulphurcontaining amino acid (cysteic, S-CM cystein, cystine and methionine), tryptophan and phenylalanine than the red once. Sulphur-containing amino acids with other organo-sulphur compounds are known to be very important for onion flavour biosynthesis (Randle, 1997).

\section{Sweetness (sugars and pungency):}

Although onions have a significant nutritional and medicinal value to the human diet, they are primarily consumed for their unique flavour and for their ability to enhance the flavour of other foods (Kopsell and Randle, 1997).

Flavour intensity in onion is dominated by organosulphur compounds arising from the enzymatic decomposition of S-alk(en)yl-L-cysteine S-oxide flavour precursors and the primary products produced include pyruvate, ammonia and sulphenic acids (Ketter and Randle, 1998). Sweetness in onion is a balance between single sugars and pungency and onions may be classified as to pungency in: very sweet $(1-4 \mu \mathrm{mol}$ pyruvic acid/g FW); sweet (5-7 $\mu$ mol pyruvic acid/g FW); intermediate pungency $(8-10 \mu \mathrm{mol}$ pyruvic acid/g FW); pungent $(11-15 \mu \mathrm{mol}$ pyruvic acid/g FW) very pungent ( $>15 \mu \mathrm{mol}$ pyruvic acid/g FW). In this work, red variety is classified as sweet and white as very sweet (Table 4). Consumption of the more pungent onion variety resulted in a more pronounced reduction in total blood cholesterol, low density lipoprotein and triglycerides, than the milder pungent cultivars. (Gabler et al., 2003). 
Table 3. Amino acids composition of onion varieties ( $\mathrm{mg} / 100 \mathrm{~g}$ of edible portion).

\begin{tabular}{|c|c|c|c|}
\hline \multirow{2}{*}{ Amino acids } & \multicolumn{2}{|c|}{ Onion variety } & \multirow{2}{*}{ Significance } \\
\hline & White & Red & \\
\hline Aspartic acid & $110 \pm 2.3$ & $81 \pm 1.5$ & $* * *$ \\
\hline Glutamic acid & $301 \pm 11.0$ & $249 \pm 10.6$ & $* * *$ \\
\hline Asparagin & $41 \pm 4.6$ & $37 \pm 2.1$ & NS \\
\hline Serine & $50 \pm 2.7$ & $43 \pm 3.8$ & $*$ \\
\hline Proline & $42 \pm 5.3$ & $26 \pm 1.9$ & $* *$ \\
\hline Glutamine & $22 \pm 0.9$ & $23 \pm 0.9$ & NS \\
\hline Glycine & $57 \pm 2.5$ & $46 \pm 0.8$ & $*$ \\
\hline Histidine & $43 \pm 3.5$ & $44 \pm 2.1$ & NS \\
\hline Threonine & $56 \pm 4.1$ & $42 \pm 3.5$ & $*$ \\
\hline Alanine & $61 \pm 2.8$ & $58 \pm 1.3$ & NS \\
\hline Arginine & $75 \pm 5.1$ & $69 \pm 2.8$ & $*$ \\
\hline Tyrosine & $48 \pm 0.8$ & $44 \pm 1.2$ & $*$ \\
\hline Ornithine & $21 \pm 0.3$ & $23 \pm 1.7$ & NS \\
\hline Tryptophan & $17 \pm 1.5$ & $49 \pm 1.3$ & $* * *$ \\
\hline Valine & $57 \pm 4.9$ & $28 \pm 0.5$ & $* *$ \\
\hline Phenylalanine & $59 \pm 3.2$ & $63 \pm 6.8$ & $*$ \\
\hline Isoleucine & $53 \pm 1.2$ & $37 \pm 0.5$ & $* *$ \\
\hline Leucine & $108 \pm 3.9$ & $88 \pm 5.2$ & $* *$ \\
\hline Lysine & $81 \pm 4.0$ & $69 \pm 2.4$ & $* *$ \\
\hline \multicolumn{4}{|l|}{ Sulphur-containing amino acids (SAA) } \\
\hline Cysteic & $41 \pm 1.7$ & $63 \pm 3.4$ & $* *$ \\
\hline S-CM cystein (S-carboxy methyl cystein) & $58 \pm 4.2$ & $65 \pm 6.2$ & $* *$ \\
\hline Cystine & $26 \pm 1.4$ & $47 \pm 1.7$ & $* *$ \\
\hline Methionine & $33 \pm 2.0$ & $51 \pm 3.4$ & $* * *$ \\
\hline Total & $1460 \pm 25.7$ & $1345 \pm 19.6$ & $* *$ \\
\hline
\end{tabular}

NS, Non significant, $\quad *, \quad * *, \quad * * *$ Significant at $\mathrm{P}<0.05, \mathrm{P}<0.01$ and $\mathrm{P}<0.0001$, respectively.

The total single sugars detected in red onion (4.78 g/100g FW) are superior to in white (3.91 g/100g FW) (Table 4). Glucose and fructose levels are higher in the red onion than the white once and the opposite with sucrose. Sugars are known to be very important for anthocyanin biosynthesis, and they can act as substrate for the synthetic pathways (Gennaro et al., 2002).

\section{Phenolic compounds:}

The term of phenolic compound embraces a wide rang of compound plant substances, which possess in common an aromatic ring bearing one or more hydroxyl substituents. They most frequently occur combined with sugar glycoside and usually located in the cell vacuole. Among the natural phenolic compounds, of which several thousand structures are known, the flavonoids form the largest group but simple monocyclic phenols and phenolic acids, anthocyanins, 
Table 4. Sugars and pungency levels in onion varieties.

\begin{tabular}{|c|c|c|c|}
\hline \multirow{2}{*}{ Sugars and pungency } & \multicolumn{2}{|c|}{ Onion variety } & \multirow{2}{*}{ Significance } \\
\hline & White & Red & \\
\hline \multicolumn{4}{|l|}{ Sugars (g/100g of edible portion): } \\
\hline Glucose & $1.33 \pm 0.19$ & $1.61 \pm 0.23$ & $* *$ \\
\hline Fructose & $1.11 \pm 0.08$ & $2.08 \pm 0.11$ & $* * *$ \\
\hline Sucrose & $1.47 \pm 0.21$ & $1.09 \pm 0.09$ & $*$ \\
\hline \multicolumn{4}{|l|}{ Pungency: } \\
\hline Pyruvic acid $(\mu \mathrm{mol} / 100 \mathrm{~g}$ of edible portion) & $6.24 \pm 0.88$ & $8.37 \pm 1.02$ & $* *$ \\
\hline
\end{tabular}

phenylpropanoids, tannins, and phenolic quinones all exist in considerable numbers. Phenolic acids are a group of phenolic compound, which may be identified as hydroxycarboxylic acids with phenolic hydroxyl groups (reviewed by Harborne, 1998). These acids are either associated with lignin combined as ester groups or present in the alcohol-insoluble fraction of the leaf; alternatively they may be present in the alcohol-soluble fraction bound as simple glycosides.

The present data indicated that two phenolic acids subgroup are found in onion i.e. benzoic and cinnamics. the red onion contains higher levels of total phenolic acids detected. Chlorogenic acid represents the major phenolic acids predominance (more than 90\%) in both varieties (Table 5). All of these data are partially in accordance with that found by others ( Emam et al., 2002). No vanillin and caffeic acids were found in these onions. Many of detected phenolic acids in onion exhibits their antioxidative (Deschamps et al., 1991; and Laranjinha et al., 1994), anticarcinogenic (Gali et al., 1991; and Harttig et al., 1996), and antibacterial (Nakane et al., 1990 and Nowosielska et al., 1991) effects.

Flavonoids are built upon a diphenylpropane skeleton $\left(\mathrm{C}_{6}-\mathrm{C}_{3}-\mathrm{C}_{6}\right)$ in which the three-carbon bridge between the phenyl groups is usually cyclized with oxygen. They are generally present in plants bound to sugar as glycosides and any one flavonoid aglycone may occur in a single plant in several glycosidic combinations. Flavonoids widely present in vegetables such as onions, are potent antioxidants (Hertog et al., 1993).

Two flavonoids subgroup are found in onion, the anthocyanins, which impart a red/purple colour to some varieties, and flavonols, such quercetin and kaempferol, responsible for the yellow and brown skins of many varieties (Griffiths et al., 2002). Such as shown in Table (5) the red onion contains higher levels of all flavonoids detected including flavonols and anthocyanins. Major flavonols in both onion varieties are quercetin compounds, quercetin-3,4'-diglucosides and quercetin-4'gluciside. For anthocyanins, delphinidin derivatives are predominant in both onion varieties as found by Rodrigues et al., (2003). Several studies reported that the red 
Table 5. Phenolic compounds levels in onion varieties (mg/100g of edible portion).

\begin{tabular}{|c|c|c|c|}
\hline \multirow{2}{*}{ Phenolic compounds } & \multicolumn{2}{|c|}{ Onion variety } & \multirow{2}{*}{ Significance } \\
\hline & White & Red & \\
\hline \multicolumn{4}{|l|}{ Phenolic acids: } \\
\hline \multicolumn{4}{|l|}{ Benzoic: } \\
\hline Gallic & $0.84 \pm 0.07$ & $1.09 \pm 0.10$ & $* *$ \\
\hline Protocatechuic & $1.68 \pm 0.11$ & $3.14 \pm 0.64$ & $* * *$ \\
\hline$p$-hydroxybenzoic & 0.00 & $0.90 \pm 0.17$ & --- \\
\hline Vanillin & 0.00 & 0.00 & --- \\
\hline \multicolumn{4}{|l|}{ Cinnamics: } \\
\hline Chlorogenic & $68.45 \pm 3.71$ & $74.96 \pm 5.32$ & $* *$ \\
\hline Caffeic & 0.00 & 0.00 & ---- \\
\hline$p$-coumaric & $0.36 \pm 0.05$ & $0.23 \pm 0.02$ & $* *$ \\
\hline Ferulic & $1.03 \pm 0.12$ & $0.98 \pm 0.09$ & NS \\
\hline Cinnamic & $0.11 \pm 0.04$ & $0.29 \pm 0.07$ & $* * *$ \\
\hline Total & $72.47 \pm 4.90$ & $81.59 \pm 7.87$ & $* *$ \\
\hline \multicolumn{4}{|l|}{ Flavonols: } \\
\hline Quercitin-4-glucoside & $18.68 \pm 2.34$ & $41.74 \pm 4.09$ & $* * *$ \\
\hline Quercitin-3-4-diglucoside & $12.42 \pm 1.29$ & $25.80 \pm 3.12$ & $* * *$ \\
\hline Kaempferol-3-O-glucoside & $0.79 \pm 0.15$ & $1.04 \pm 0.08$ & $* *$ \\
\hline Quercitin & $0.41 \pm 0.07$ & $1.17 \pm 0.12$ & $* *$ \\
\hline Isoquercitin & $0.19 \pm 0.03$ & $0.63 \pm 0.07$ & $* * *$ \\
\hline Total & $32.49 \pm 4.25$ & $70.38 \pm 6.23$ & $* * *$ \\
\hline \multicolumn{4}{|l|}{ Anthocyanins: } \\
\hline $\begin{array}{l}\text { Delphinidin diglucosylglucoside } \\
+ \text { petunidin diglucoside }\end{array}$ & $2.44 \pm 0.22$ & $4.15 \pm 0.44$ & $* *$ \\
\hline Delphinidin glucosylglucoside & $2.03 \pm 0.11$ & $2.97 \pm 0.23$ & $*$ \\
\hline Delphinidin & $0.27 \pm 0.06$ & $0.31 \pm 0.09$ & NS \\
\hline Petunidin & $0.16 \pm 0.03$ & $0.13 \pm 0.05$ & NS \\
\hline Total & $4.90 \pm 0.82$ & $7.56 \pm 0.98$ & $* *$ \\
\hline
\end{tabular}

NS, Non significant, $\quad *, \quad * *, * * *$ Significant at $\mathrm{P}<0.05, \mathrm{P}<0.01$ and $\mathrm{P}<0.0001$, respectively.

bulb colour is influenced by anthocyanin contents (Griffiths et al., 2002 and Rodrigues et al., 2003).

With the nutritional point of view, it has been demonstrated that humans absorb part of the quercetin glucosides accumulating them as quercetin conjugates in the blood plasma (Ioku, 2002). Quercetin prevents oxidation of low density lipoproteins (LDL) in vitro by scavenging to free oxygen radicals. Its intake was inversely associated with coronary heart mortality possibly because flavonoids are able to inhibit platelet aggregation in vitro (Hollman et al, 1996 and Furusawa et al., 2003). Also, many flavonoids exhibit a wide range of biological effects, including antibacterial, antiviral, anti-inflammatory, antiallergic, antithrombotic, and vasodilatory actions (Cook and Sammon, 1996). 
Antioxidant activity. The antioxidant activities and total phenolics of white and red onion varieties are shown in Table (6). The decrease in absorbance of $\beta$ carotene in the presence of different methanolic onion extracts (and well-known antioxidants used as standards) with the oxidation of $\beta$-carotene and linoleic acid is shown in Figure (1). The antioxidant activity of red onion bulbs methanolic extract is superior to in white when it was calculated by the four different methods used in this study. The relationship between total phenolics content and antioxidant activity of onion bulbs is shown in Tables (8-9). The results indicated that when all onion varieties were included in the statistical analysis, there was a positive significant $(\mathrm{p}<$ 0.05 ) relationship between total phenolics including phenolic acids, flavonoids and anthocyanins and antioxidant activity. Also, the same relationship was observed between antioxidant activity and many other factors include Se and sulphurcontaining amino acids. This indicates that total phenolic compounds beside other factors including Se and sulphur-containing amino acid can play a major role in the antioxidant activity of onion bulbs. In similar study, Velioglu et al., (1998) reported that the correlation coefficient between total phenolics and antioxidative activities of 28 plant products, including sunflower seeds, flaxseeds, wheat germ, buckwheat, several fruits, vegetables, and medicinal plants was statistically significant. Also, Lee et al., (1995) reported that phenolic compounds including flavonoids, correlated well with antioxidant activity $\left(\mathrm{r}^{2}=0.86\right)$ in 5 cultivars of fresh pepper (Capsicum annuum).

Table 6. Antioxidant activity and total phenolics of methanolic extracts of White and Red onion.

\begin{tabular}{lccccc}
\hline Sample name & $\begin{array}{c}\text { Antioxidant } \\
\text { value } \\
\text { AOX (A/h) }\end{array}$ & $\begin{array}{c}\text { Antioxidant } \\
\text { activity } \\
\text { AA (\%) }\end{array}$ & $\begin{array}{c}\text { Oxidation } \\
\text { rate ratio } \\
\text { (ORR) }\end{array}$ & $\begin{array}{c}\text { Antioxidant } \\
\text { activity } \\
\text { coefficient } \\
\text { (AAC) }\end{array}$ & $\begin{array}{c}\text { Total phenolics } \\
\text { (mg/100 g) }\end{array}$ \\
\hline White onion & $0.182 \pm$ & $67.83 \pm$ & $0.321 \pm$ & $351.51 \pm$ & $131.65 \pm$ \\
& 0.011 & 2.21 & 0.020 & 23.11 & 19.17 \\
Red onion & $0.155 \pm$ & $72.65 \pm$ & $0.273 \pm$ & $435.30 \pm$ & $187.17 \pm$ \\
Control & 0.009 & 3.09 & 0.012 & 30.14 & 33.89 \\
BHT, 50 & $0.569 \pm$ & & $1.000 \pm$ & & \\
mg/L & 0.023 & 0.00 & 0.09 & 0.00 & \\
BHT, 200 & $0.076 \pm$ & $86.54 \pm$ & $0.134 \pm$ & $676.77 \pm$ & \\
mg/L & 0.012 & 1.89 & 0.018 & 11.98 & \\
& $0.010 \pm$ & $98.31 \pm$ & $0.017 \pm$ & $881.39 \pm$ & \\
ó-tocopherol, & 0.002 & 1.06 & 0.008 & 21.00 & \\
$\mathbf{5 0 ~} \mathbf{m g} / \mathbf{L}$ & $0.011 \pm$ & $98.11 \pm$ & $0.019 \pm$ & $877.91 \pm$ & \\
\hline
\end{tabular}




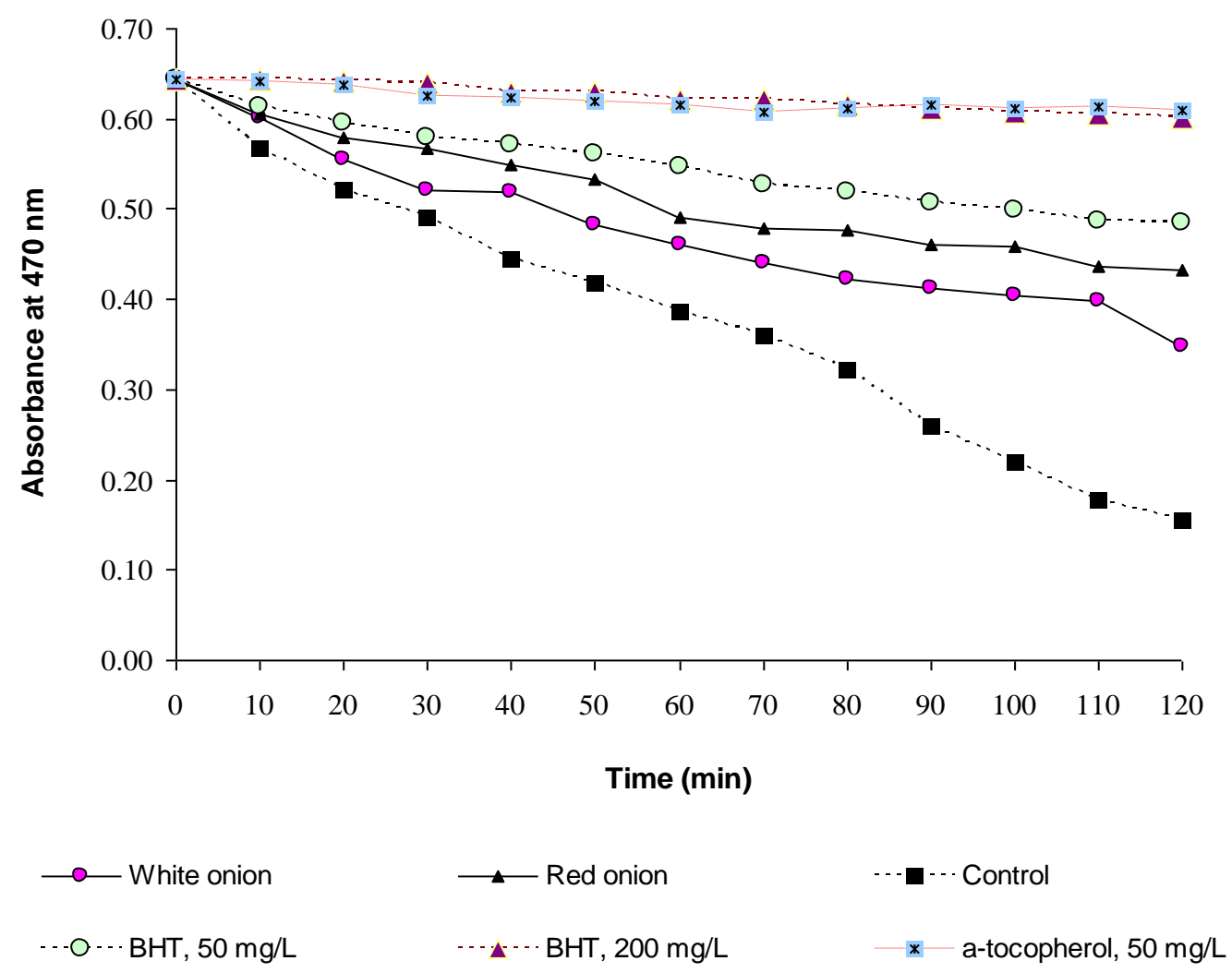

Figure 1. Antioxidant activity (Abs at $470 \mathrm{~nm}$ ) of methanolic extracts of onion bulbs assayed by the $\beta$-carotene bleaching method (BHT at $50 \mathrm{mg} / \mathrm{L} \& 100 \mathrm{mg} / \mathrm{L}$ and $\alpha-$ tocopherol at $50 \mathrm{mg} / \mathrm{L}$ concentrations were used as references).

In addition, correlation studies indicated that pungency is highly correlated with sulphur content, vitamin $\mathrm{C}$, fructose, sulphur-containing amino acids and phenolics including flavonols and anthocyanins (Table 7) and we found that onions with more sulphur, fructose, sulphur-containing amino acids and phenolics are more pungent. Such data are convenient with that mentioned by Randle et al., (1998) mentioned that pungency, measured as pyruvate, vary between genotypes and growing conditions. The genetic system of onion controls sulphur uptake and assimilation of the sulphur and, increased sulphate fertility, higher growing temperatures and dry growing conditions all contribute to increased flavour intensity in onion (Randle, 1997and Ketter and Randle, 1998).

In general, the data of this study with the others proved the importance of using selected onion varieties and/or extracts as natural potent antioxidants in both therapy and food technology. The antioxidant activity of onion bulbs could be attributed mainly to the high levels of total phenolic (phenolic acids, flavonols and anthocyanins) beside Se and sulphur-containing amino acids. Many studies indicated that feeding of phenolic acid (ellagic) significantly increased the levels of reduced 
glutathione and glutathione reductase in liver and lungs of male and female mice as well as increase in inhibition of NADPH-dependent lipid peroxidation (Majid et al., 1991). The antioxidant activity of four phenolic acids like detected in onion bulbs, upon low density lipoprotein peroxidation were studied in vitro in a low density lipoprotein (LDL) oxidation model by Laranjinha et al., (1994). The addition of these acids exhibits a complex reaction with peroxyl radicals resulting in undefined inhibition periods of LDL oxidation and low reactivity with peroxyl radicals. Presumably, secondary radicals of these compounds are unable to initiate LDL oxidation. Several researchers have investigated the antioxidative activity of flavonoids compounds and have attempted to define the structural characteristics of flavonoids that contribute to their activity (Nieto et al., 1993; and Foti et al., 1996). Also, $\mathrm{Se}$ is an essential trace element. Its importance for human and animal metabolism has become apparent more recently, spurred by the discovery of a Sedependent enzyme, glutathione peroxidase (widely distributed in tissues), and suggestive evidence that selenium plays a role in the prevention of certain forms of cancer (reviewed by Linder, 1991). Regarding to food technology applications, there are beneficial effects of onion addition to some foods, like traditional sausage "chouriço" to maintain oxidative stability. That is due to its flavonoid content, mainly quercetin, because they are potent antioxidants and function by interrupting the free radical chain in the propagation step of the oxidative process (Karastogiannidou, 1999). Also, the adding of phenolic acids including in onion bulbs to vegetable oils leads to significant decrease in the rate of hydrolysis, rancidity and formation of the toxic and carcinogenic substances during the deep frying process (Elhassaneen et al., 2004).

In conclusion, the Egyptian onion varieties studied evidenced a great variability in chemical composition due mainly to genetic factors and growing conditions. Onions with more sulphur, fructose, sulphur-containing amino acids and phenolic compounds are more pungent. The antioxidant activity of red onion bulbs methanolic extract is superior to in white once. Correlation analysis indicates that total phenolic compounds beside other factors including Se and sulphur-containing amino acid contents play the major role in the antioxidant activity of onion bulbs. Therefore, white variety shows higher nutritional value while the potential health benefits related to the presence of antioxidant compounds and other factors were higher in red variety.

Further work is in progress in our laboratory to elucidate the possibility of using the highly antioxidant activity of onion bulbs extracts in many nutritional and food technology applications.

\section{Acknowledgements}

Financial support for this study partially provided by New Beni Suef Company for Preservation, Dehydration and Industrization of vegetables, Shinnawy (Beni Suef El Guedida, Nile East, Beni Suef, Egypt) is gratefully acknowledged. Also deep thanks are extended to chemists Rasha R. and Marwa M., New Beni Suef Company for Preservation, Dehydration and Industrization of vegetables, for lab assistance and samples preparation. 


\section{REFERENCES}

A.O.A.C. (1995). "Official Methods of the Association of Official Analytical Chemists" $16^{\text {th }}$ Ed. Published by the Association of Official Analytical Chemists. Arlington, Virginia, USA.

Al-Saikhan, M. S.; Howard, L. R. and Miller, J. C., Jr. (1995). Antioxidant activity and total phenolics in different genotypes of potato (Solanum tuberosum, L.). J. Food Sci., 60 (2), 341-343.

APHA, (1999). Vanadonolybdophosphoric acid colorimetric method. In: Standard methods for the examination of water and wastewater. American Public Health Association, American Water Works

Campos, K.; Diniz, Y.; Cataneo, A.; Faine, L. ; Alves, M. and Novelli, E. (2003). Hypoglycaemic and antioxidant effects of onion, Allium cepa: dietary onion addition, antioxidant activity and hypoglycaemic effects on diabetic rats. Inter. J. Food Sci. Nutr., 54 (3): 241-246.

Cook, N. C. and Samman, S (1996). Flavonoids chemistry, metabolism, cardioprotective effects, and dietary sources. Nutr. Biochem., 7, 66-76.

Deschamps, D.; Fisch, C.; Fromenty, B.; Berson, A.; Degott, C. and Pessayre, D. (1991). Inhibition by salicylic acid of the activation and oxidation of long chain fatty acids: Possible role in the development of Reye's syndrome. $J$. Pharmacol. Exp. Ther., 259,2: 894-904.

Elhassaneen, Y.A. (2004). The effect of charcoal broiled meat consumption on antioxidant defence system of erythrocytes and antioxidant vitamins in plasma. Nutri. Res., 24 (6): 435 - 446.

El-Sadany, M.A. (2001). The effect of dietary phytochemicals on the prevention of liver cancer initiation induced by some chemical carcinogenesis. M.Sc. Thesis, Fac. of Home Economics, Minufiya University, Shebin El-Kom, Egypt.

Emam, O.A.; Tawfik, L.M.; Hussein, M.A.; Elhassaneen, Y. A and El-Nahas, O. (2002). Studies on some fresh and processed vegetables and fruits as a source of anticarcinogenic phytochemicals. Egypt. J. Nutr., XVII, (3): 197 -226.

FAOSTAT, (2002). Agriculture Data. Food Balance Sheets. URL: http://apps.fao.org.

Fossen, T.; Andersen, O. M.; Ovstedal, D. O.; Pedersen, A. T.; Raknes, A. (1996). Characteristic anthocyanin pattern from onions and other Allium spp. J. Food Sci., 61: $703-711$.

Foti, M.; Piattelli, M.; Baratta, M. T.; Ruberto, G. (1996). Flavonoids, coumarins and cinnamic acids as antioxidants in a micellar system. Structure- activity relationship. J. Agric. Food Chem., 44: 497-501.

Furusawa, M.; Tsuchiya, H.; Nagayama, M.; Tanaka, T.; Nakaya, K. and Iinuma, M. (2003). Anti-Platelet and membrane rigidifying flavonoids in brownish scale of onion. J. of Health Sci., 49 (6): 475-480. 
Gabler, N.K.; Ostrowska, E.; Jones, R.B.; Imsic, M.; Jois, M.; Tatham, B.G.; Eagling, D.R. and Dunshea, F.R. (2003). Consumption of brown onion (Allium cepa) cultivars reduce the risk factors of cardiovascular disease. Australian Postharvest Horticulture Conference, Brisbane, Australiapp. 178179.

Gali, H.U.; Perchellet, E.M. and Perchellet, J. P. (1991). Inhibition of tumor promoter-induced ornithine decarboxylase activity by tannic acid and other polyphenols in mouse epidermis in vivo. Cancer Res., 51 (11): 2820-2825.

Gennaro, L.; Leonardi, C.; Esposito, F.; Salucci, M.; Maiani, G.; Quaglia, G. and Fogliano, V. (2002). Flavonoid and carbohydrate contents in Tropea red onions: Effects of homelike peeling and storage. J. Agric. Food Chem., 50:1904 -1910

Griffiths, G.; T, L.; Crowther, T.; Thomas, B. and Smith, B., (2002). Onions- A global benefit to health. Phytother. Res., 16 (7):603-615 .

Harborne, J.B. (1998). Phytochemical Methods: A guige to modern techniques of plant analysis. The $3{ }^{\text {rd }}$ Ed., Chapman \& Hall, London.

Harttig, U.; Hendricks, J.D.; Stoner, G.D. and Bailey, G.S. (1996). Organ specific, protocol dependent modulation of 7,12-dimethylbenz[a]anthracene carcinogenesis in rainbow trout (Oncorhynchus mykiss) by dietary ellagic acid. Carcinogenesis, 17 (11): 2403-2409.

Hertog, M.G.L.; Feskens, E.J.M.; Hollman, P.C.H.; Katan, M.B. and Kromhout D., (1993). Dietary antioxidant flavonoids and the risk of coronary heart disease: the Zutphen Elderly Study. Lancet , 40: 1591-1598.

Hertog, M.G.L.; Hollman, C. H. and Venema, D. P., (1992). Optimization of a quantitative HPLC determination of a potentially anticarcinogenic flavonoids in vegetables and fruits. J. Agric. Food Chem., 40:1591-1598 .

Hollman, P.C.; vd Gaag, M.; Mengelers, M.J.; van Trijp, J.M.; de Vries, J.H. and Katan M.B..(1996). Absorption and disposition kinetics of the dietary antioxidant quercetin in man. Free Radic Biol., 21(5): 703-707.

Huang, M.T. and Ferraro, T. (1992). Phenolic compounds in food and their effects on health. In: Haung, C.T. and Lee, C.Y. (Editors), II (ASC symposium series, no. 507), American Chemical Society, Washington, DC, pp. 8.

Ioku, K., (2002). Bioavailability of quercetin glucosides in onion. Foods Ingredients $J$. Japan, 201 (abstract).

Ismail, A.M.; Sedki, A.A. and Abdallah, A.G. (2003). Influence of black seed, garlic and onion supplementation on reproductive performance in rabbits. Egypt. J. Agric. Res., 81(3):1193-1207.

Kamal, A. and Daoud, J. (2003). Effect of onion and/or garlic as feed additives on blood, tissue constituents and growth performance in Muscovy ducks. Vet. Med. J., 51(2): 161-175

Karastogiannidou, C., (1999). Effects of onion quercitin on oxidative stability of cook-chill chicken in vacuum-sealed containers. J. Food Sci., 64 (6): 978-981. 
Ketter, C.A. and Randle, W.M., (1998). Pungency assessment in onions. In: S J Karcher (Ed.) Tested studies for laboratory teaching, Vol. 19, Association for Biology Laboratory Education (ABLE) pp.177-196 .

Kopsell, D.E. and Randle W M, (1997). Onion cultivars differ in pungency and bulb quality changes during storage. Hort. Science, 32 (7): 1260-1263 .

Laranjinha, J.; Almeida, L. and Madeira, V. (1994). Reactivity of dietary phenolic acids with peroxyl radicals: antioxidant activity upon low-ensity lipoprotein peroxidation. Biochem. Pharmacol.,48(3): 487-494.

Larson, R. A. (1988). The antioxidants of higher plants. Phytochem., 27(4), 969-978.

Lee, Y.; Howard, L.R. and Villalon, B. (1995). Flavonoids and antioxidant activity of fresh pepper (Capsicum annuum) cultivars. J. Food Sci., 60 (3) : 473-476.

Linder, M.G. (1991). Nutritional Biochemistry and Metabolism, Prentice Hall International Limited, London, UK.

Lindroth, P. and Mopper, K. (1979). HPLC determination of subpicomole amounts of amino acids by precolumn fluorescence derivatization with $\mathrm{O}$ phthaldialdehyde. Anal. Chem., 51(11): 1667-1674.

Majid, S.; Khanduja, K.L.; Gandhi, R.K.; Kapur, S. and Sharma, R.R. (1991). Influence of ellagic acid on antioxidant defense system and lipid peroxidation in mice. Biochem. Pharmacol., 42(7): 1441-1445.

Mallett, J. F.; Cerrati, C.; Ucciani, E.; Gamisana, J. and Gruber, M. (1994). Antioxidant activity of plant leaves in relation to their a-tocopherol content. Food Chem., 49, 61-65.

Marco, G. J. (1968). A rapid method for evaluation of antioxidants. J. Am. Oil Chem. Soc., 45: 594-598.

Marinova, E. M.; Yanishlieva, N. and Kostova, I. N. (1994). Antioxidative action of the ethanolic extract and some hydroxycoumarins of Fraxinus ornus bark. Food Chem., 51: 125-132.

Moeslinger, T.; Brunner M. and Spieckermann, G. (1994). Spectrophotometric determination of dehydroascorbic acid in biological samples. Annals. Biochem., 221: 290 - 296.

Nakane, H.; Fukushima, M. and Ono, K. (1990). Differential inhibition of reverse transcriptase and various DNA polymerase by digallic acid and its derivatives. J. Nat. Prod. Lloydia., 53(5): 1234-1240.

Nieto, S.; Garrido, A.; Sanhueza, J.; Loyola, L.; Morales, G.; Leighton, F. and Valenzuela, A. (1993). Flavonoids as stabilizers offish oil: an alternative to synthetic antioxidants. J. Am. Oil Chem. Soc., 70:773-778.

Niki E. (1991). Action of ascorbic acid as a scavenger of active and stable oxygen radicals. Am. J. Clin. Nutr. 54: 1119S-1124S.

Nowosielska, Z.I.; Grzybek, J.; Manolova, N.; Serkedjieva, J. and Zawilinska, B. (1991). Antiviral activity of Flos verbasci infusion against influenza and Herpes simplex viruses. Arch. Immunol. Ther. Exp., 39(1-2):103-108.

Onyencho, S.N. and Hettiarachchy, N.S. (1993). Antioxidant activity, fatty acids and phenolic acids compositions of potato peels. J. Sci. Food Agric., 62: 345350 . 
Packer, L, (1992). Interaction among antioxidants in health and disease; Vit. E and its redox cycle. Proc. Soc. Exp. Biol. Med. ,200:271-278.

Randle, W. M. (1997). Onion flavour chemistry and factors influencing flavour intensity. In: S. J . Rish and C. Tang (Ed.), Spices: Flavor chemistry and antioxidant properties, American Chemical Society, pp. 41-52 .

Randle, W.M.; Kopsell, D.A., Kopsell, D.E., Snyder, R.L. and Torrance, R. (1998). Field sampling short-day onions for bulb pungency. Hort. Technology, 8:329-332 .

Rodrigues, A.S.; Fogliano, V.; Graziani, G.; Mendes, S.; Vale, A.P. and Goncalves, C. (2003). Nutritional value of onion regional varieties in Northwest Portugal, Electron. J. Environ. Agric. Food Chem., 2(4).

Schwimmer, S. and Weston, W.J. (1961). Enzymatic development of pyruvic acid in onion as a measure of pungency. Agric. Food Chem. , 9(4): 301-4 .

Singh, K.; Sundarro, K.; Tinkerame, J.; Kaluwin, C. and Matsuoka, T. (1991). Lipid content fatty acid and mineral composition of Mud Crabs (Seylla serrate) from Papua new Guinea. J. Food Comp. Anal., 4 (3): 276 - 280.

Singleton, V. L. and Rossi, J. A., Jr. (1965). Colorimetry of total phenolics with phosphomolybdic-phosphotungstic acid reagents. Am. J. Enol. Vitic., 16: 144158.

Teyssier C.; Amiot M. J., Mondy N., Auger J., Kahane R. and Siess M.H., (2001). Effect of onion consumption by rats on hepatic drug-metabolizing enzymes. Food and Chem. Toxicol., 39(10): 981-987.

Velioglu, Y.S.; Mazza, G.; Gao, L. and Oomah, B.D. (1998). Antioxidant activity and total phenolics in selected fruits, vegetables and grain products. J. Agric. Food Chem., 46 (10): 4113-4117.

Wang, B.; Chen, J. ; Liang, Y. and Duh, P. (2005). Effects of Welsh onion on oxidation of low-density lipoprotein and nitric oxide production in macrophage cell line RAW 264.7. Food Chem., 91(1):147-155. 


\title{
محتوى المركبـات الفينوليـة ودرجـة الحـلاوة والأحمـاض الأمينيـة لأصناف البصل

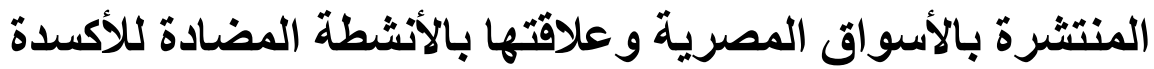

\author{
يوسف عبد العزيز الحسانين

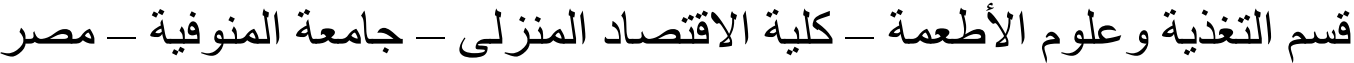

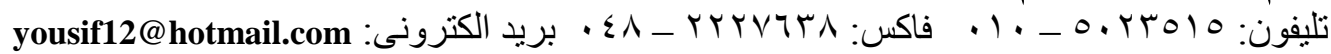

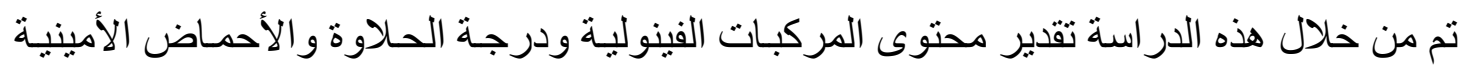

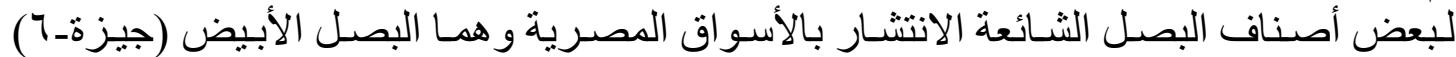

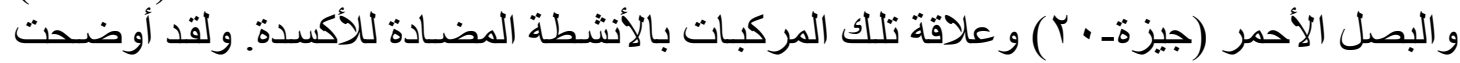

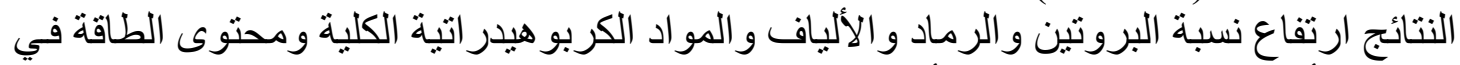

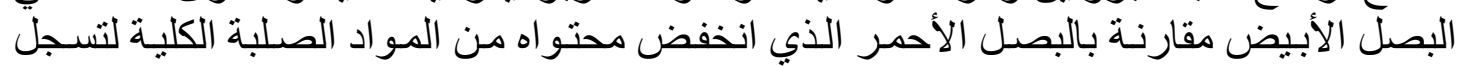

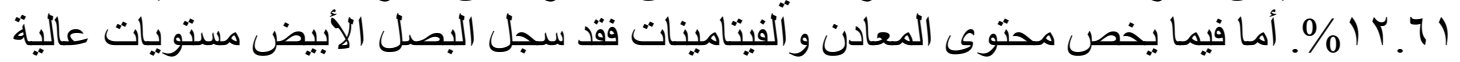
من البوتاسيوم و الكالسيوم و الماغنيسيوم و الفوسفور و والزنكانك و النحاس و المنجنيز في حين سجل

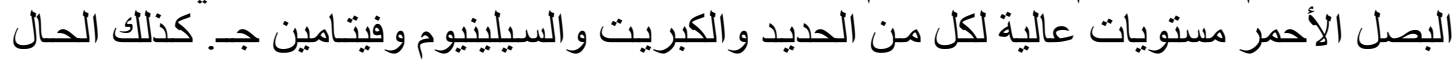

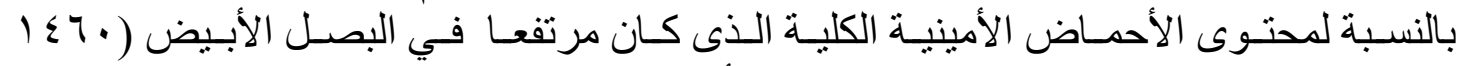
ملجم/ • . جر ام وزن رطب) مقارنة بالبصل الأحمر (

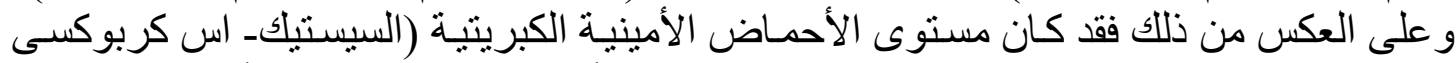

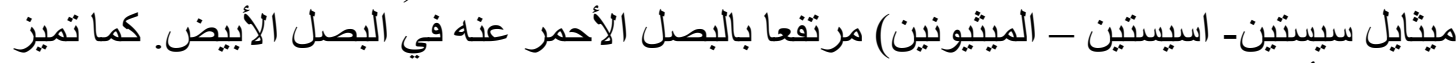

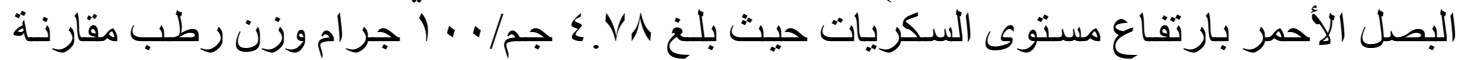

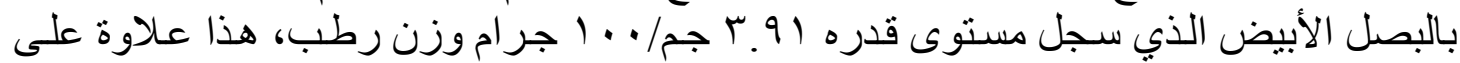

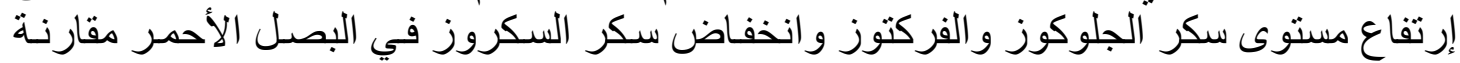

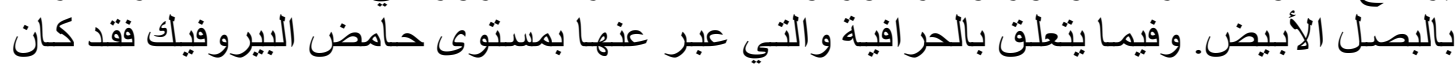

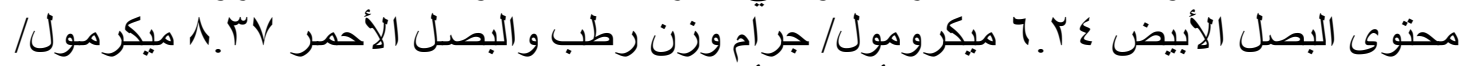

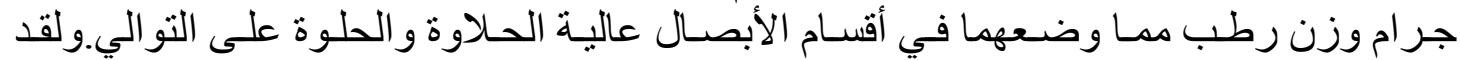

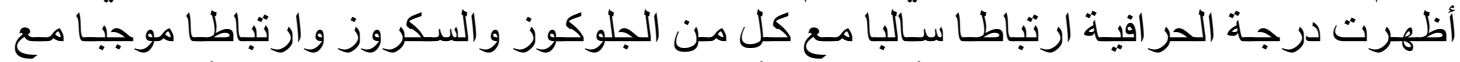

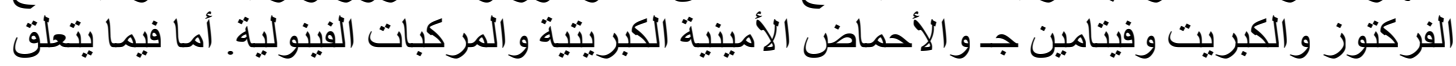

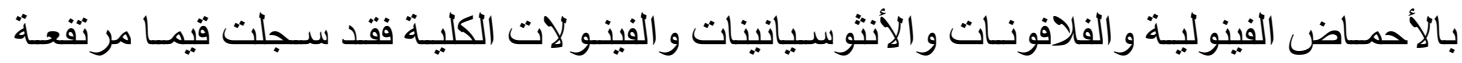

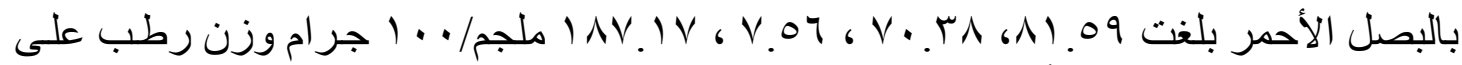

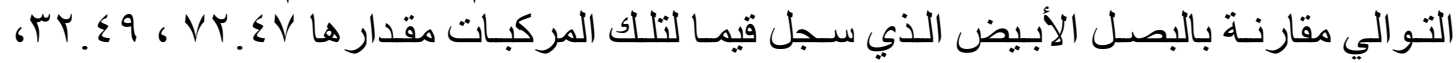

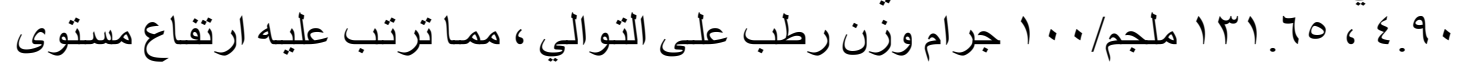

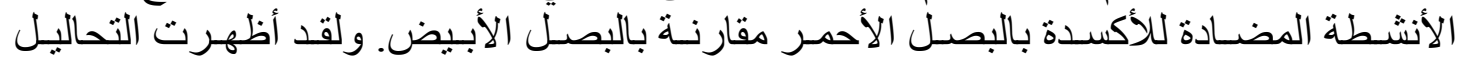

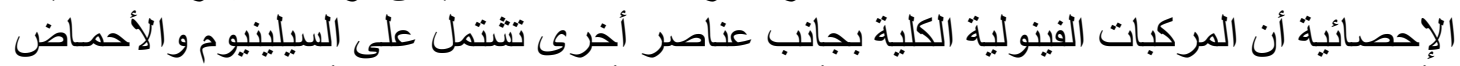

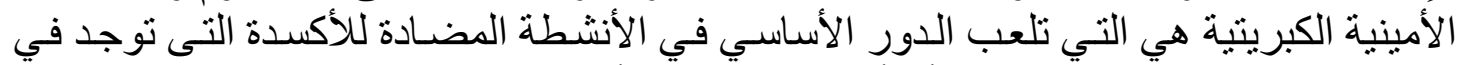

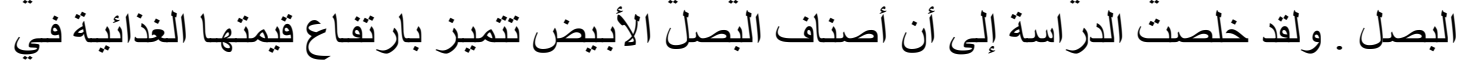

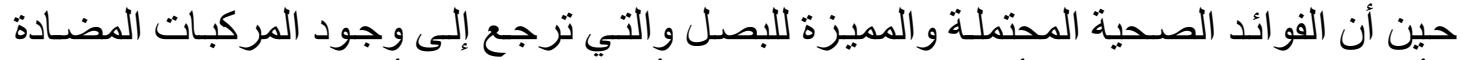
للأكسدة مع بعض العو امل الأخرى كانت مرتفعة في أصناف البحلف البصل الأحمر. 
